\title{
Adenosine as a signaling molecule in the retina: biochemical and developmental aspects*
}

\author{
ROBERTO PAES-DE-CARVALHO \\ Department of Neurobiology and Program of Neuroimmunology, Institute of Biology \\ Federal Fluminense University, 24001-970 Niterói, RJ, Brazil \\ Manuscript received on June 18, 2002; accepted for publication on June 25, 2002; \\ presented by Fernando G. DE Mello
}

\begin{abstract}
The nucleoside adenosine plays an important role as a neurotransmitter or neuromodulator in the central nervous system, including the retina. In the present paper we review compelling evidence showing that adenosine is a signaling molecule in the developing retina. In the chick retina, adenosine transporters are present since early stages of development before the appearance of adenosine A1 receptors modulating dopamine-dependent adenylate cyclase activity or A2 receptors that directly activate the enzyme. Experiments using retinal cell cultures revealed that adenosine is taken up by specific cell populations that when stimulated by depolarization or neurotransmitters such as dopamine or glutamate, release the nucleoside through calciumdependent transporter-mediated mechanisms. The presence of adenosine in the extracellular medium and the long-term activation of adenosine receptors is able to regulate the survival of retinal neurons and blocks glutamate excitoxicity. Thus, adenosine besides working as a neurotransmitter or neuromodulator in the mature retina, is considered as an important signaling molecule during retinal development having important functions such as regulation of neuronal survival and differentiation.
\end{abstract}

Key words: nucleoside, receptors and transporters, development, cell culture, uptake and release.

\section{INTRODUCTION}

The original demonstration by Sattin and Rall (1970) that the nucleoside adenosine regulates adenylate cyclase activity was followed by many studies that had stablished adenosine as an important signalling molecule in vertebrates. The presence of adenosine-sensitive adenylate cyclase was detected in several tissues and cell types (Premont et al. 1977, de Vente and Zaagsma 1981, Anand-Srivastava and

\footnotetext{
*This work is dedicated to the memory of Dr. Carlos Chagas Filho, founder of the Institute of Biophysics of the Federal University of Rio de Janeiro, for his enormous contribution for the formation of generations of students and brazilian scientists. Correspondence to: Roberto Paes-de-Carvalho E-mail: robpaes@vm.uff.br
}

Franks 1985). The regulation of adenylate cyclase by adenosine analogs is mediated through different mechanisms depending on their chemical structure. For example, analogs modified in the purine moiety promote adenylate cyclase stimulation or inhibition whereas analogs modified in the ribose only promote inhibition of the enzyme. Based on these differences, analogs were then classified as " $R$ " site or " $\mathrm{P}$ " site agonists, depending if they were respectively modified in the purine or ribose moieties (Londos and Wolff 1977, Newman 1983). The R sites were further identified as surface receptors and $P$ sites as intracellular sites on the enzyme adenylate cyclase (Nimit et al. 1982, Johnson and Shoshani 
1990, Dessauer and Gilman 1997).

The distinction between adenosine surface receptors and intracellular sites was demonstrated in some ellegant pioneering studies that showed the existence of two types of surface receptors named A1 and A2 receptors (Van Calker et al. 1979, Londos et al. 1980). A1 receptors are negatively coupled to adenylate cyclase while A2 receptors are positively coupled to the enzyme. Begginining in the decade of 1980, several studies were able to measure adenosine receptors using binding protocols (Wu et al. 1980, Goodman et al. 1982, Bruns et al. 1983, 1986, Yeung and Green 1984, Stiles 1985). Specially important in this case was the discovery that large amounts of adenosine are released from intact tissues or homogenates and compete with the binding of labeled adenosine or analogs. The preincubation with adenosine deaminase, an important enzyme of the adenosine catabolism that promotes the elimination of endogenous adenosine and formation of the inactive compound inosine, was a procedure to detect the binding of high affinity deaminaseresistant analogs to adenosine receptors.

Recently, cloning studies have revealed the existence of subtypes of $\mathrm{A} 2$ receptors (A2a and $\mathrm{A} 2 \mathrm{~b}$ ) and also A3 receptors (Snell et al. 2000, d'Alcantara et al. 2001, Johansson et al. 2001, Talukder et al. 2002). The surface receptors for adenosine, with the exception of A3 receptors, are antagonized by methylxanthines (van Gallen et al. 1994, Klinger et al. 2002), while the actions via " $P$ "' sites are blocked by adenosine transport inhibitors. Studies with knockout mutants have revealed many important functions of adenosine receptors such as the regulation of inflammation (Ohta and Sitkovsky 2001).

Besides its distribution in several tissues, adenosine receptors are widely distributed in the central nervous system. Although A2 receptors seem to be concentrated in the striatum of adult animals (Fink et al. 1992, Marala and Mustafa 1993), very little is know about the development of these receptors and localizations in the embryo. The A1 receptors present a wider distribution and many studies have stablished a presynaptic localization for these receptors (Oliet and Poulain 1999, Poli et al. 2001) where they can regulate the release of excitatory neurotransmitters (Goodman et al. 1983).

\section{ADENOSINE IN THE RETINA}

The retina, a part of the central nervous system, is a very useful model for the study of development of neurotransmitter systems (Fung et al. 1982, Messersmith and Redburn 1993, Salceda and Vilchis 1994, Johansson et al. 2000, Johansson and Ehinger 2001). Indeed, many studies showed the ontogeny of GABA, dopamine, glutamate, acetylcholine and other systems in the chick retina (de Mello et al. 1976, Araki et al. 1983, 1984, Ventura et al. 1984, Lankford et al. 1988, Ventura and de Mello 1990, Huba and Hofmann 1991, Shah and Hausman 1993, Calvet and Ventura 1995, Paes-de-Carvalho et al. 1996, Sampaio and Paes-de-Carvalho 1998, Soares et al. 2000). The purinergic system is also present in the retinas of several species (Blazynski and Perez 1991) participating in the control of cone photoreceptor movements (Rey and Burnside 1999) or regulating waves of spontaneous neural activity (Stellwagen et al. 1999).

Here we will review some aspects of the development of the adenosine system in the chick retina.

\section{I - Adenosine-dependent Adenylate Cyclase IN THE Chick Embryo Retina}

The presence of an adenosine-dependent adenylate cyclase activity was first described in the chick embryo retina (Paes-de-Carvalho and de Mello 1982) and also detected in the mammalian retina (Blazynski et al. 1986). The increase of cyclic AMP levels of 17-day-old (E17) chick embryo retinas was 3-4 times larger with RO20-1724 than with IBMX, two different phosphodiesterase inhibitors. The higher level obtained with RO20-1724 could be inhibited by adenosine deaminase or IBMX, an adenosine antagonist, and under these conditions could be stimulated with 2-chloroadenosine, an adenosine deaminase-resistant analog. The data indicated that 
endogenous adenosine released from incubated retinas is able to stimulate adenylate cyclase. The elevation of cyclic AMP levels promoted by the activation of A2 adenosine receptors was first detected at E14, a period in which the first synaptic contacts are observed in the tissue, increasing in subsequent days up to E17 and decreasing thereafter, attaining low levels in the post-hatching period (figure 1).

\section{II - Development of A1 Receptors in the}

RETINA: INTERACTIONS WITH THE DOPAMINERGIC SySTEM

Dopamine receptors coupled to adenylate cyclase are also present in the chick retina and their stimulation promotes cyclic AMP accumulation since E7 (de Mello 1978). In an attempt to study the interaction of the two adenylate cyclase systems (adenosine and dopamine -dependent) present during development of the chick retina, we performed experiments using retinas from E17 embryos, a stage in which the two systems coexist in the retina (Paesde-Carvalho and de Mello 1985). We found that the accumulation of cyclic AMP by dopamine and adenosine was not additive using saturating or subsaturating concentrations of both ligands. One hypothesis for this discrepancy was the presence of inhibitory A1 adenosine receptors in the tissue. Indeed, we decided to test this hypothesis stimulating retinas from E10 embryos, a stage in which dopamine-dependent cyclic AMP accumulation is observed but not the accumulation of cyclic AMP by adenosine. We then found that at this stage adenosine analogs were able to promote a dose-dependent decrease of dopamine-dependent cyclic AMP accumulation. This effect was mediated by the activation of A1 receptors as demonstrated by pharmacological studies. The maximal inhibition attained was approximately $70 \%$ (figure 1). On the other hand, the maximal cyclic AMP accumulation induced by the mixed dopaminergic agonist apomorphine was only $30 \%$ of that observed with dopamine at E8 and, at the post-hatching period, the effects of dopamine or apomorphine were small. Interestingly, adeno- sine was not able to inhibit the effect of apomorphine at all developmental stages as well the effect of dopamine at the post-hatching period (figure 1). It was proposed the existence of two types of dopamine receptors coupled to adenylate cyclase in the chick retina, one present only in the early periods of development that could be regulated by adenosine interacting with $\mathrm{A} 1$ receptors and a second type that is stimulated by both dopamine and apomorphine, is present throughout development and also in the post-hatching period and that is not regulated by adenosine (Paes-de-Carvalho and de Mello 1985). These studies raised the possibility for the existence of embryonic subtypes of dopamine D1 and adenosine A1 receptors that could be playing important roles during development of the retina. This idea was strengthened by the finding that dopamine could regulate neurite outgrowth of retinal neurons (Lankford et al. 1988) and that two subtypes of D1 receptors are expressed in the developing retina (Soares et al. 2000). However, although the regulation of dopamine-dependent cyclic AMP accumulation was no longer detected in post-hatched retinas (figure 1), adenosine analogs are able to inhibit forskolin-stimulated cyclic AMP levels in posthatched retinas (Paes-de-Carvalho 1990), indicating that these receptors are still present at this stage possibly playing a different role but not related to the stimulation of dopamine receptors. Binding studies confirmed these findings showing that A1 receptor density varies strinkingly during retinal development being present since E10, attaining a maximum at E17 and decreasing to a constant level at posthatched retinas (Paes-de-Carvalho 1990). The presence of $\mathrm{A} 1$ adenosine receptors regulating adenylate cyclase activity was also detected in the mammalian retina (Blazynski 1987).

\section{III - Localization Studies of Adenosine and} AdENOSINE ReCEPTORS

The presence of adenosine as well as adenosine receptors were first characterized in the retina by immunocytochemistry and receptor autoradiography 


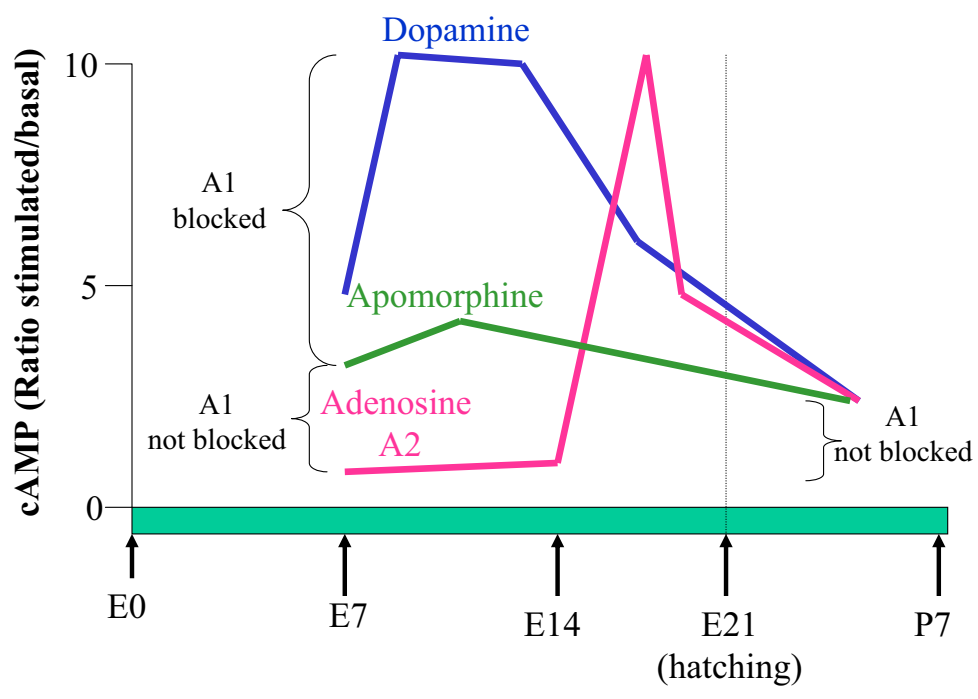

Fig. 1 - Summary of changes of cyclic AMP levels stimulated by activation of dopamine and adenosine receptors during development of the chick retina. Dopamine receptors were stimulated by dopamine or the partial agonist apomorphine. Note the difference in the stimulated/basal ratio when retinas were exposed to dopamine or apomorphine in the embryonic period while the ratio is similar at the post-hatching period. The activation of adenosine A1 receptors blocks the stimulation by dopamine, but not apomorphine, in the embryonic retina. At the post-hatching period, the effects of both dopamine or apomorphine are not regulated by $\mathrm{A} 1$ receptors.

by Braas et al. (1986, 1987). These authors showed the presence of adenosine and adenosine A1 receptors predominantly localized in the ganglion cell layer of mammalian retinas. Other studies revealed by autoradiography the uptake of $\left({ }^{3} \mathrm{H}\right)$ adenosine into horizontal cells in the goldfish retina (Studholme and Yazulla 1997), cells located in the ganglion cell layer of mammalian retina (Blazynski 1989) and cells that display GABA immunoreactivity in the chicken and rabbit retina (Perez and Bruun 1987). However, further studies with the chick retina showed the localization of adenosine immunoreactivity in ganglion cells, amacrine cells and also photoreceptors (Paesde-Carvalho et al. 1992). The same study showed that $\mathrm{A} 1$ adenosine receptors are detected since E12 in the plexiform layers of developing and mature retinas.

\section{IV - Adenosine Transport Sites}

The presence of nucleoside transporters was described in several tissues and central nervous system areas (Cass et al. 1998, Baldwin et al. 1999, Parkinson 1999) and subdivided in two major subclasses, concentrative (CNTs, sodium-dependent) and equilibrative (ENTs, sodium-independent) (Visser et al. 2002). The equilibrative transporters are ubiquitously distributed and further classified as sensitive (es or ENT1) or insensitive (ei or ENT2) to the inhibitor Nitrobenzylthioinosine (NBI). The es subtype has a widespread distribution and seems to be the major transporter in the CNS (Anderson et al. 1999, Sinclair et al. 2001). The binding of the nucleoside inhibitors $\left({ }^{3} \mathrm{H}\right)$ dipyridamol and $\left({ }^{3} \mathrm{H}\right) \mathrm{NBI}$ was detected in the CNS (Deckert et al. 1988 a,b, Marangos and Deckert 1987). In the chick retina, 
$\left({ }^{3} \mathrm{H}\right)$ NBI binding is detected since early stages of development (E8) up to post-hatched animals (Paesde-Carvalho et al. 1992). Autoradiograhic experiments revealed the presence of transport sites distributed throughout the tissue at E8, suggesting the expression of these sites in neuroblasts. Interestingly, A1 or A2 receptors could not be detected at this developmental stage. At later stages of development, the transporters could be localized predominantly in the plexiform layers in localizations similar to that found for A1 receptors (Paes-de-Carvalho et al. 1992).

\section{CELL CULTURE EXPERIMENTS}

Many neurotransmitter systems are expressed in cultures of retinal cells in a similar manner as in the developing intact tissue (Mockel et al. 1994, Cossenza and Paes-de-Carvalho 2000, Sholl-Franco et al. 2000, 2001, Yasuyoshi et al. 2002). Different types of retinal cultures can be used for the study of neurotransmitters and other signaling molecules: High-density mixed cultures containing neurons and glial cells (monolayers or aggregates) and purified cultures of neurons or glial cells (de Mello et al. 1982, Paes-de-Carvalho et al. 1990, Cossenza and Paes-de-Carvalho 2000, de Almeida et al. 2002). In the next sections we will describe experiments performed using the retinal cultures to study the properties of the adenosine system in the retina.

\section{I - Adenosine-dependent Adenylate Cyclase}

The accumulation of cyclic AMP induced by adenosine was also detected in high-density monolayer cultures of chick retinal cells (de Mello et al. 1982, Paes-de-Carvalho and de Mello 1982). The effect is observed as soon as 1 day after plating retinal cells from 8-day-old embryos (E8C1), increases after E8C3 and attains maximal levels at E8C4. The incubation of cultures for 72 hours with adenosine promoted a 3-fold decrease in the cyclic AMP accumulation induced by the nucleoside, suggesting that the A2 receptors can be desensitized or downregulated during a long-term exposure of cells to adenosine (de Mello et al. 1982). Although the A2 receptor-mediated cyclic AMP accumulation is detected in the monolayer cultures, no inhibition of dopamine-dependent adenylate cyclase mediated by A1 receptors were found in these cultures, in opposition of what is observed in the intact retina or cultured cell aggregates (Paes-de-Carvalho 1987), probably reflecting differences in the expression of A1 receptors (see section $\mathrm{V}$ below).

\section{II - AdENOSINE IMmUNOCYTOCHEMISTRY AND UP-} TAKE

Adenosine immunoreactivity as well as uptake and release processes for the nucleoside were extensively studied in purified cultures of retinal neurons and photoreceptors (Paes-de-Carvalho et al. 1990). Adenosine immunoreactive cells are abundant in these cultures and detected as early as six hours after seeding the cells (Paes-de-Carvalho et al. 1990). In 6 day-old cultures (E8C6), virtually all photoreceptors are labeled whereas around $40 \%$ of neurons display immunoreactivity.

Adenosine is taken up by purified cultures of retinal neurons through a very active mechanism that can be blocked by dipyridamole or NBI, indicating the predominance of the es transporter subtype (Paes-de-Carvalho et al. 1990). The uptake is temperature-dependent, sodium-independent and abolished when $\left({ }^{3} \mathrm{H}\right)$ adenosine is preincubated with adenosine deaminase, indicating that the process is specific for adenosine and not for inosine. Uptake autoradiographic experiments show that about $50 \%$ of neurons and all photoreceptors are labeled. Double-labeling experiments performed using $\left({ }^{3} \mathrm{H}\right)$ adenosine uptake autoradiography and adenosine immunostaining showed that while virtually all photoreceptors and about $40 \%$ of neurons are double-labeled, small populations of neurons (around $10 \%$ each) were positive only for autoradiographic grains or adenosine immunoreactivity. The significance of these results are presently unknown but probably reflects intense metabolism of adenosine after uptake into neurons. 


\section{III - RELEASE EXPERIMENTS}

The radioactivity taken up by the cells when exposed to $\left({ }^{3} \mathrm{H}\right)$ adenosine could be released after depolarization with high potassium concentrations, an effect that is blocked by removing calcium ions from the extracellular medium, indicating that adenosine is released from retinal neurons in culture by a calcium-dependent mechanism. However, the analysis of extracellular radioactivity revealed that $70 \%$ of released material is found as inosine and only $10 \%$ as adenosine. Similar findings were reported by Perez et al. (1986) using intact rabbit retina. One hypothesis would be that inosine is synthezised from adenosine taken up by neurons and released after depolarization. Alternatively, adenosine is released and converted to inosine in the extracellular medium by an ecto adenosine deaminase (Franco et al. 1997). A third alternative would be the release of ATP and conversion to adenosine and inosine by ecto-nucleotidases and ecto-deaminase (Dunwiddie et al. 1997, Santos et al. 1999). Although this possibility is feasible because of the high conversion of taken up adenosine to nucleotides in retinal cultures, we were unable to block the detection of adenosine and metabolites in the released material using nucleotidase inhibitors such as $\alpha \beta$-methylene ADP plus GMP (Knofel and Strater 2001).

Dopamine and glutamate are also able to promote the release of radioactivity when retinal cells in culture are previously labeled with $\left({ }^{3} \mathrm{H}\right)$ adenosine. Figure 2 shows the result of experiments in which these pre-labeled cultures were stimulated with dopamine. The release is observed with 10 or $100 \mu \mathrm{M}$ dopamine and is reversible upon removal of exogenous dopamine. The release by glutamate is mediated by the activation of NMDA receptors and blocked in the absence of calcium in the extracellular medium or by NBI (Paes-de-Carvalho R, Dias BV and Martins RA unpublished results), indicating that the release is mediated by the transporter and by a calcium-dependent process. Our recent unpublished data also show that both the uptake and release stimulated by glutamate are inhibited by the
CAMKII inhibitors KN62 or KN93, indicating that the transport is modulated by this enzyme activity.

\section{IV - Binding Studies of Transporter Sites}

The presence of adenosine uptake sites was also detected by binding of $\left({ }^{3} \mathrm{H}\right) \mathrm{NBI}$ to live cells in highdensity retinal cultures. The kinetic analysis showed that equilibrium is attained after 10 minutes and could be reversed after addition of unlabeled NBI (figure 3 ). The binding was saturable and showed one class of sites with a $\mathrm{Kd}$ of $1.94 \pm 0.56 \mathrm{nM}$. Interestingly, $B_{\max }$ values, but not $\mathrm{K}_{\mathrm{d}}$ values, decreased when cultures were pre-treated for 5 days in the presence of $100 \mu \mathrm{M}$ adenosine plus $10 \mu \mathrm{M}$ EHNA, an adenosine deaminase inhibitor (figure 4), suggesting that the number of transporters in the plasma membrane can be modulated by the presence of adenosine in the extracellular medium. Moreover, the uptake capacity is also decreased in the cultures exposed to adenosine (not shown).

\section{V - Studies on the EXPRESSION OF A1 RECEPTORS in Retinal Cultures}

As described above, the presence of A1 adenosine receptors was demonstrated in the chick retina since early developmental stages. These receptors were detected by binding studies (Paes-de-Carvalho 1990) and also by the inhibition of cyclic AMP accumulation induced by dopamine (Paes-de-Carvalho and de Mello 1985) or forskolin (Paes-de-Carvalho 1990). However, this inhibitory effect was observed in cultures of retinal aggregates but not in monolayer cultures (Paes-de-Carvalho 1987). Although some studies revealed the presence of A1 binding sites in monolayers of chick retinal cells (Santos et al. 1998a,b), our recent data show the absence of $\left({ }^{3} \mathrm{H}\right)$ DPCPX or $\left({ }^{3} \mathrm{H}\right)$ CCPA binding sites in these cultures. This discrepancy could be related to the amount of cell aggregation found in the cultures, since preliminary experiments show an increase of A1 receptors in aggregate cultures or monolayer cultures in which the cells were poorly dissociated before seeding (Paes-de-Carvalho R and Pereira MR 


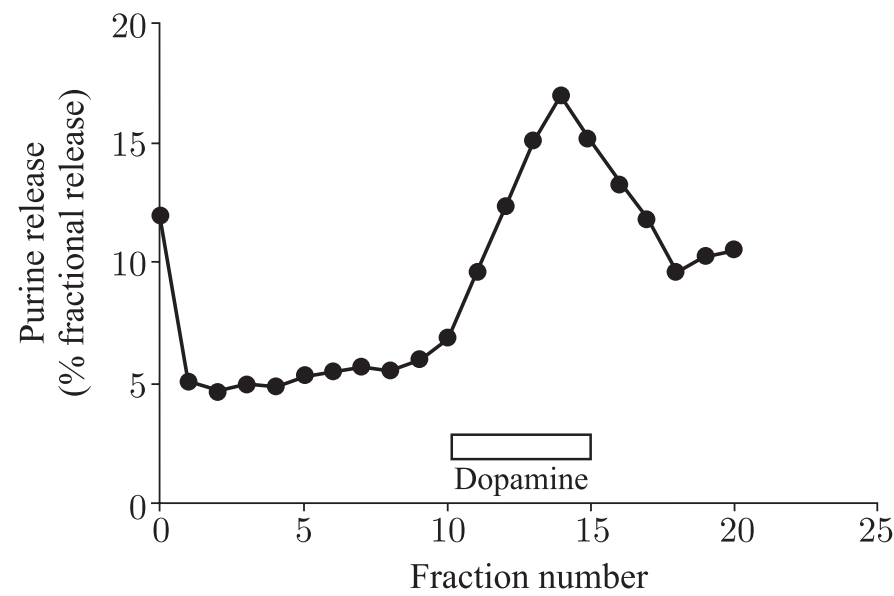

Fig. 2 - Effect of dopamine on the release of purines in cultures of chick retinal neurons. Purified retinal neuronal cultures were obtained from E8 chick embryos and incubated for 2 days. Cultures were then washed and incubated with saline containing $\left({ }^{3} \mathrm{H}\right)$ adenosine $(0.2 \mu \mathrm{M})$ for 15 minutes at $37^{\circ} \mathrm{C}$. After further washing cultures were successively incubated with normal saline for 10 periods of 1 minute, then incubated for 5 periods of 1 minute with saline containing dopamine $(100 \mu \mathrm{M})$ and finally incubated for 5 periods of 1 minute with normal saline. Note the increase in purine release stimulated by dopamine and the reversibility after returning to normal saline.

unpublished results). Moreover, the number of A1 receptor sites is greatly increased in cultures treated with 8-bromo cyclic AMP, suggesting that the expression or activity of these receptors are regulated by the activity of PKA.

\section{Vi - Modulation of Acetylcholine Release By A1 AdENosine ReCEPTORS}

Adenosine is considered as a modulator of transmitter release in the CNS and several reports showed a modulation of glutamate, acetylcholine and serotonin release from presynaptic terminals (Santos et al. 2000, Okada et al. 2001, Marchi et al. 2002). Recently, Santos et al. (1998a,b, 2000) showed that the activation of $\mathrm{A} 1$ receptors modulates the release of acetylcholine from cultured retinal cells. This effect was due to a selective inhibition of N-type calcium channels coupled to the release of acetylcholine, but not of GABA, and in a Pertussis toxin sensitive way (Santos et al. 1998a,b, 2000). More- over, these authors demonstrated that the release of acetylcholine in the cultures is under a tonic inhibition by endogenous adenosine present in the cultures (Santos et al. 1998a,b).

\section{ADENOSINE SIGNALING AND NEURONAL SURVIVAL}

The neuroprotective effect of adenosine is well stablished (Fredholm 1997, Dunwiddie and Masino 2001) in several CNS areas where the nucleoside is liberated during hypoxia and ischemia (Coelho et al. 2000, Dale et al. 2000) as well as during epileptiform activity (Berman et al. 2000). It is believed that the neuroprotective effect of adenosine is mediated by activation of A1 receptors although some reports indicate a participation of A2a receptors (Ongini et al. 1997, Johansson et al. 2001). In the retina, adenosine plays a protective role in ischemia-reperfusion injury (Roth 1995) possibly through activation of $\mathrm{A} 1$ and $\mathrm{A} 2 \mathrm{a}$ receptors ( $\mathrm{Li}$ et al. 1999). 


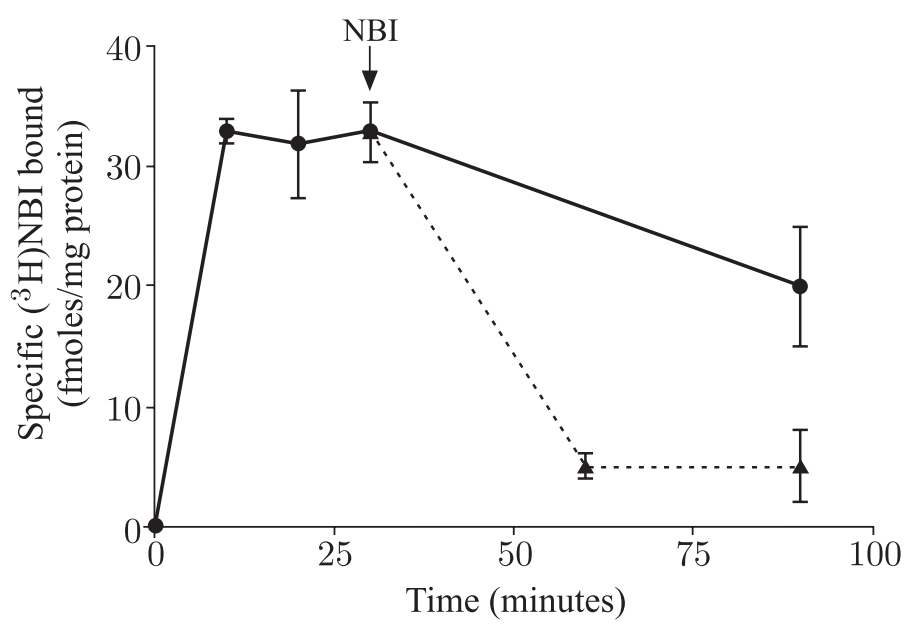

Fig. 3 - Time profile of specific $\left({ }^{3} \mathrm{H}\right) \mathrm{NBI}$ binding to adenosine transporters in cultures of chick retinal cells. Cultures were incubated for 6 days and incubated with saline containing $\left({ }^{3} \mathrm{H}\right) \mathrm{NBI}(10 \mathrm{nM})$ in the absence or presence of unlabeled NBI $(10 \mu \mathrm{M})$ for determination of specific binding. Maximal binding was observed after 10 minutes and was stable for at least more 20 minutes. The addition of unlabeled NBI after 30 minutes of incubation was able to displace $\left({ }^{3} \mathrm{H}\right) \mathrm{NBI}$ binding (dashed line) from cultured cells, indicating the binding to surface sites.

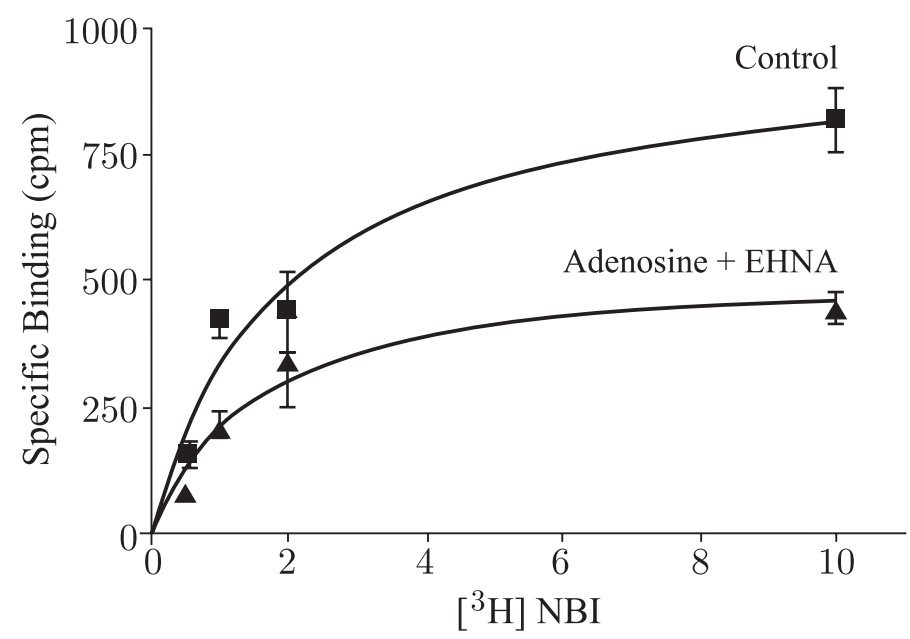

Fig. 4 - Effect of adenosine treatment on the binding of $\left({ }^{3} \mathrm{H}\right) \mathrm{NBI}$ to cultured retinal cells. Control cultures or cultures treated for 5 days with adenosine $(100 \mu \mathrm{M})$ plus EHNA $(10 \mu \mathrm{M})$, an adenosine deaminase inhibitor, were incubated in saline containing increasing concentrations of $\left({ }^{3} \mathrm{H}\right) \mathrm{NBI}$ in the absence or presence of unlabeled NBI $(10 \mu \mathrm{M})$ for determination of specific binding. A significant reduction of $B_{\max }$ values were observed in treated cultures $(975.6 \pm 106.3$ to $533.1 \pm 74.9 \mathrm{cpm})$ but not of $\mathrm{K}_{\mathrm{d}}(1.9 \pm 0.6$ to $1.5 \pm 0.6)$, indicating a decrease in the number but not the affinity of transporters. 
During early embryonic development, after arrest of cell division, retinal cells differentiate and migrate to their definitive positions in the tissue (Spence and Robson 1989), whereas the subsequent programmed cell death stablishes the final number of cells. The biochemical and developmental processes that control cell death are currently under study (for a review see Linden et al. 1999). Noteworthy, the precise timing of ocurrence of the phenomenon is believed to be regulated by specific biochemical mechanisms that are possibly under control of extracellular signals such as neurotrophic factors and neurotransmitters (Araujo and Linden 1993, Varella et al. 1999). In the following sections we describe experiments that indicate adenosine as an important modulator of neuronal survival as well as a neuroprotective substance.

\section{I - Adenosine Regulates the Survival of Neu- RONS AND PHOTORECEPTORS IN CULTURE}

The presence of adenosine markers such as receptors, transport sites and coupling to second messenger systems during early development of the retina suggested a possible role of the nucleoside as a signalling molecule during early retinal development. Our recent results indicate that one role of the nucleoside is to regulate neuronal survival. When purified cultures of retinal neurons and photoreceptors are refed with fresh medium they display an intense death of both neurons and photoreceptors, an effect that can be greatly reduced when the cultures are preincubated with adenosine (Paes-de-Carvalho and Maia 1996). The protective effect is mimicked by A2a adenosine receptor agonists, the uptake blocker NBI or cyclic AMP analogs, but not A1 receptor agonists. The cell death was also observed when cultures were incubated with adenosine deaminase but not when cultures were refed with a conditioned medium obtained from "sister" cultures (Paes-deCarvalho R, Maia G and Ferreira JM unpublished results). The data strongly indicate that the presence of adenosine is essential for neuronal survival in the cultures playing a trophic function per se or regu- lating the secretion or response to specific trophic factors.

\section{II - Adenosine Blocks Glutamate Excitotoxi- City in Retinal Neuronal Cultures}

When retinal neurons in culture are exposed to glutamate, an extensive cell death is observed that is prevented by MK 801, an NMDA receptor antagonist, or DNQX, an AMPA/kainate antagonist (Ferreira and Paes-de-Carvalho 2001). Kainate also promotes a similar excitotoxic effect that is blocked by MK 801, indicating that the cell death is mediated by the activation of NMDA receptors. Noteworthy, preincubation of cultures with adenosine, NBI or cyclic AMP analogs promotes an intense neuroprotection from the excitotoxic effects of glutamate or kainate. The effect can be observed with a preincubation of 2 hours but is maximal with 24 hours, indicating the need for a long-term exposure of cells to the nucleoside to occur the neuroprotection. A2a receptor agonists such as CGS 21680 or DPMA, but not the A1 agonist CHA, have similar protective effects, demonstrating the importance of $\mathrm{A} 2 \mathrm{a}$ receptors coupled to adenylate cyclase in the phenomenon. The results highlight the role of adenosine as a regulator of cell survival in the developing retina.

\section{CONCLUSIONS AND PERSPECTIVES}

Although the data reviewed in this paper strongly support the role of adenosine as a neurotransmitter in the adult retina and also as a modulator of neuronal survival and differentiation during development, much work still remains do be done in order to elucidate the mechanisms of action of the nucleoside in the adult or developing retina. For example, the transduction pathways involved in adenosine actions appear to involve more than the regulation of adenylate cyclase and PKA since the nucleoside regulates PKC and also MAP kinases in other tissues (Linden et al. 1998, Arslan and Fredholm 2000). The regulation of these pathways could have important roles in the retina specially during devel- 
opment. Our recent experiments demonstrate that adenosine stimulates ERK1/2 in purified cultures of glial cells via activation of A1 receptors (Silva IA, Leão-Ferreira L and Paes-de-Carvalho R unpublished results). Interestingly, this effect is not observed in mixed high-density cultures, suggesting that this response is modulated by neurons. Moreover, although adenosine is accumulated in photoreceptors, amacrine and ganglion cells and A1 receptors and adenosine transporters are visualized in the retinal plexiform layers, the cell localization of the receptors is unclear. Further work is necessary using specific antibodies against the different adenosine receptors in order to localize the receptors among the different cell types in the retina and to study their expression during development. The data presented in this review also showed important effects of adenosine as a survival factor and neuroprotective molecule in the retina. Recent results from our laboratory shows that long-term activation of adenosine receptors modulates the expression of NMDA glutamate receptors in cultures of retinal cells (Ferreira JM and Paes-de-Carvalho R unpublished results), an effect mimicked by cyclic AMP analogs. The mechanisms involved in these effects of adenosine and the possible relations with neurodegenerative diseases also deserve further studies.

\section{ACKNOWLEDGMENTS}

This work was supported by the Brazilian National Research Council (CNPq) and the Research Foundation of Rio de Janeiro (FAPERJ). We wish to thank the staff of the laboratory of Cellular Neurobiology for helpful discussions.

\section{RESUMO}

O nucleosídeo adenosina apresenta um importante papel como neurotransmissor ou neuromodulador no sistema nervoso central, inclusive na retina. Neste artigo apresentamos uma revisão das evidências que mostram que a adenosina é uma molécula sinalizadora na retina em desenvolvimento. Na retina de pinto, transportadores de adenosina estão presentes desde estágios precoces do de- senvolvimento, antes do aparecimento dos receptores A1 que modulam a atividade adenilato ciclase dependente de dopamina ou dos receptores A2 que ativam diretamente a enzima. Experimentos usando culturas de células de retina revelaram que a adenosina é captada por populações celulares específicas que, quando estimuladas por despolarização ou por neurotransmissores tais como dopamina ou glutamato, liberam o nucleosídeo através de mecanismos dependentes de cálcio e mediados por transportador. A presença de adenosina no meio extracelular e a ativação duradoura dos receptores de adenosina regula a sobrevivência de neurônios da retina e bloqueia a excitoxicidade mediada por glutamato. Desse modo, a adenosina, além de apresentar a função de neurotransmissor ou neuromodulador na retina desenvolvida, é considerada como uma molécula importante durante o desenvolvimento da retina, apresentando funções como a regulação da sobrevivência e diferenciação neuronal.

Palavras-chave: nucleosídeo, receptores e transportadores, desenvolvimento, cultura de células, captação e liberação.

\section{REFERENCES}

AnAND-Srivastava MB and Franks DJ. 1985. Stimulation of adenylate cyclase by adenosine and other agonists in mesenteric artery smooth muscle cells in culture. Life Sci 37: 857-867.

Anderson CM, Xiong W, Geiger JD, Young JD, Cass CE, Baldwin SA and Parkinson FE. 1999. Distribution of equilibrative, nitrobenzylthioinosinesensitive nucleoside transporters (ENT1) in brain. J Neurochem 73: 867-873.

Araki M, Maeda T and Kimura H. 1983. Dopaminergic cell differentiation in the developing chick retina. Brain Res Bull 10: 97-102.

Araki M, Saito T, Takeuchi Y and Kimura H. 1984. Differentiation of monoamine accumulating neuron systems in cultured chick retina: an immunohistochemical and fluorescence histochemical study. Brain Res 317: 229-237.

Araujo EG and Linden R. 1993. Trophic factors produced by retinal cells increase the survival of retinal ganglion cells in vitro. Eur J Neurosci 5: 1181-1188. 
Arslan G and Fredholm BB. 2000. Stimulatory and inhibitory effects of adenosine A2a receptors on nerve growth factor-induced phosphorylation of extracellular regulated kinases $1 / 2$ in PC12 cells. Neurosci Lett 292: 183-186.

Baldwin SA, Mackey JR, Cass CE and Young JD. 1999. Nucleoside transporters: molecular biology and implications for therapeutic development. Mol Med Today 5: 216-224.

Berman RF, Fredholm BB, Aden U and O'Connor WT. 2000. Evidence for increased dorsal hippocampal adenosine release and metabolism during pharmacologically induced seizures in rats. Brain Res 872: 44-53.

Blazynski C. 1987. Adenosine A1 receptor-mediated inhibition of adenylate cyclase in rabbit retina. J Neurosci 7: 2522-2528.

Blazynski C. 1989. Displaced cholinergic, GABAergic amacrine cells in the rabbit retina also contain adenosine. Vis Neurosci 3: 425-431.

Blazynski C and Perez MT. 1991. Adenosine in vertebrate retina: localization, receptor characterization, and function. Cell Mol Neurobiol 11: 463-484.

Blazynski C, Kinscherf DA, Geary KM and FerRENDELLI JA. 1986. Adenosine-mediated regulation of cyclic AMP levels in isolated incubated retinas. Brain Res 366: 224-229.

Braas KM, Newby AC, Wilson VS and Snyder SH. 1986. Adenosine-containing neurons in the brain localized by immunocytochemistry. J Neurosci 6 : 1952-1961.

BraAs KM, Zarbin MA and SNyder SH. 1987. Endogenous adenosine and adenosine receptors localized to ganglion cells of the retina. Proc Natl Acad Sci USA 84: 3906-3910.

Bruns RF, DALY JW ANd SNyder SH. 1983. Adenosine receptor binding: structure-activity analysis generates extremely potent xanthine antagonists. Proc Natl Acad Sci USA 80: 2077-2080.

Bruns RF, Lu GH And Pugsley TA. 1986. Characterization of the A2 adenosine receptor labeled by $[3 \mathrm{H}] \mathrm{NECA}$ in rat striatal membranes. Mol Pharmacol 29: 331-346.

Calvet GA and Ventura AL. 1995. Accumulation of $3 \mathrm{H}$-phosphoinositides mediated by muscarinic re- ceptors in the developing chick retina: inhibition of carbachol-induced response by glutamate receptors. J Neurochem 64: 1064-1070.

Cass CE, Young JD and BALdwin SA. 1998. Recent advances in the molecular biology of nucleoside transporters of mammalian cells. Biochem Cell Biol 76: 761-770.

Coelho JE, de Mendonca A and Ribeiro JA. 2000. Presynaptic inhibitory receptors mediate the depression of synaptic transmission upon hypoxia in rat hippocampal slices. Brain Res 869: 158-165.

Cossenza M and Paes-de-Carvalho R. 2000. Larginine uptake and release by cultured avian retinal cells: differential cellular localization in relation to nitric oxide synthase. J Neurochem 74: 1885-1894.

D'Alcantara P, Ledent C, Swillens S and SchiffMANN SN. 2001. Inactivation of adenosine A2a receptor impairs long term potentiation in the accumbens nucleus without altering basal synaptic transmission. Neuroscience 107: 455-464.

Dale N, Pearson T and Frenguelli BG. 2000. Direct measurement of adenosine release during hypoxia in the CA1 region of the rat hippocampal slice. J Physiol 526: 143-155.

de Almeida OM, Gardino PF, Loureiro dos Santos NE, Yamasaki EN, de Mello MC, Hokoç JN and DE Mello FG. 2002. Opposite roles of GABA and excitatory amino acids on the control of GAD expression in cultured retina cells. Brain Res 925: 89-99.

DE Mello FG. 1978. The ontogeny of dopamine-dependent increase of adenosine 3',5'-cyclic monophosphate in the chick retina. J Neurochem 31: 10491053.

de Mello FG, Bachrach U and Nirenberg M. 1976. Ornithine and glutamic acid decarboxylase activities in the developing chick retina. J Neurochem 27: 847851.

de Mello MCF, Ventura AlM, Paes-De-Carvalho R, Klein WL and de Mello FG. 1982. Regulation of dopamine and adenosine-dependent adenylate cyclase systems of chicken embryo retina cells in culture. Proc Natl Acad Sci USA 79: 5708-5712.

DE Vente J And ZaAgsma J. 1981. Effects of adenosine and adenosine-analogs on adenylate cyclase activity in the rat adipocyte plasma membrane: comparison 
of the properties of the enzyme with $\mathrm{Mn} 2+$ and $\mathrm{Mg} 2+$ as divalent cations. Mol Cell Biochem 40: 65-73.

Deckert J, Bisserbe JC, Klein E and Marangos PJ. 1988a. Adenosine uptake sites in brain: regional distribution of putative subtypes in relationship to adenosine A1-receptors. J Neurosci 8: 2338-2349.

Deckert J, Morgan PF, Daval JL, Nakajima T and Marangos PJ. 1988b. Ontogeny of adenosine uptake sites in guinea pig brain: differential profile of $[3 \mathrm{H}]$ nitrobenzylthioinosine and $[3 \mathrm{H}]$ dipyridamole binding sites. Brain Res 470: 313-316.

Dessauer CW and Gilman AG. 1997. The catalytic mechanism of mammalian adenylyl cyclase. Equilibrium binding and kinetic analysis of P-site inhibition. J Biol Chem 272: 27787-27795.

Dunwiddie TV and Masino SA. 2001. The role and regulation of adenosine in the central nervous system. Annu Rev Neurosci 24: 31-55.

Dunwiddie TV, Diao L and Proctor WR. 1997. Adenine nucleotides undergo rapid, quantitative conversion to adenosine in the extracellular space in rat hippocampus. J Neurosci 17: 7673-7682.

Ferreira JM ANd PAES-DE-CARVAlho R. 2001. Longterm activation of adenosine A2a receptors blocks glutamate excitotoxicity in cultures of avian retinal neurons. Brain Res 900: 169-176.

Fink JS, Weaver DR, Rivkees SA, Peterfreund RA, Pollack AE, Adler EM ANd Reppert SM. 1992. Molecular cloning of the rat A2 adenosine receptor: selective co-expression with D2 dopamine receptors in rat striatum. Mol Brain Res 14: 186-195.

Franco R, Casado V, Ciruela F, Saura C, Mallol J, Canela EI and Lluis C. 1997. Cell surface adenosine deaminase: much more than an ectoenzyme. Prog Neurobiol 52: 283-294.

Fredholm BB. 1997. Adenosine and neuroprotection. Int Rev Neurobiol 40: 259-280.

Fung SC, Kong YC and Lam DM. 1982. Prenatal development of GABAergic, glycinergic, and dopaminergic neurons in the rabbit retina. J Neurosci 2: $1623-$ 1632.

Goodman RR, CoOper MJ, Gavish M AND SNyder SH. 1982. Guanine nucleotide and cation regulation of the binding of $[3 \mathrm{H}]$ cyclohexyladenosine and [3H]diethylphenylxanthine to adenosine A1 recep- tors in brain membranes. Mol Pharmacol 21: 329335 .

Goodman RR, Kuhar MJ, Hester L and Snyder SH. 1983. Adenosine receptors: autoradiographic evidence for their location on axon terminals of excitatory neurons. Science 220: 967-969.

Huba R And Hofmann HD. 1991. Transmitter-gated currents of GABAergic amacrine-like cells in chick retinal cultures. Vis Neurosci 6: 303-314.

Johansson B, Halldner L, Dunwiddie TV, Masino SA, Poelchen W, Gimenez-Llort L, Escorihuela RM, Fernandez-Teruel A, WiesenfeldHallin Z, Xu XJ, Hardemark A, Betsholtz C, Herlenius E and Fredholm BB. 2001. Hyperalgesia, anxiety, and decreased hypoxic neuroprotection in mice lacking the adenosine A1 receptor. Proc Natl Acad Sci USA 98: 9407-9412.

Johansson K And Ehinger B. 2001. Postnatal development of the rat retina and some of its neurotransmitter systems in vitro. Prog Brain Res 131: 589-98.

Johansson K, Bruun A, Grasbon T and Ehinger B. 2000. Growth of postnatal rat retina in vitro. Development of neurotransmitter systems. J Chem Neuroanat 19: 117-228.

JoHnSON RA AND SHOSHANi I. 1990. Kinetics of "P'”site-mediated inhibition of adenylyl cyclase and the requirements for substrate. J Biol Chem 265: 11595 11600 .

Klinger M, Freissmuth M and Nanoff C. 2002. Adenosine receptors: $\mathrm{G}$ protein-mediated signalling and the role of accessory proteins. Cell Signal 14: 99-108.

Knofel T and Strater N. 2001. Mechanism of hydrolysis of phosphate esters by the dimetal center of 5 '-nucleotidase based on crystal structures. J Mol Biol 309: 239-254.

Lankford KL, de Mello FG and Klein WL. 1988. D1-type dopamine receptors inhibit growth cone motility in cultured retina neurons: evidence that neurotransmitters act as morphogenic growth regulators in the developing central nervous system. Proc Natl Acad Sci USA 85: 2839-2843.

Li B, Jennings NM, Rosembaum PS, Maxwell KM AND Roth S. 1999. Differential effects of adenosine receptor subtypes in retinal ischemia-reperfusion in- 
jury in rats. Exp Eye Res 68: 9-17.

Linden J, Auchampach JA, Jin X And Figler RA. 1998. The structure and function of $\mathrm{A} 1$ and $\mathrm{A} 2 \mathrm{~B}$ adenosine receptors. Life Sci 62: 1519-1524.

Linden R, Rehen SK and Chiarini LB. 1999. Apoptosis in developing retinal tissue. Prog Ret Eye Res 18: $133-165$.

Londos C And WolfF J. 1977. Two distinct adenosinesensitive sites on adenylate cyclase. Proc Natl Acad Sci USA 74: 5482-5486.

Londos C, Cooper DM And WolfF J. 1980. Subclasses of external adenosine receptors. Proc Natl Acad Sci USA 77: 2551-2554.

Marala RB and Mustafa SJ. 1993. Direct evidence for the coupling of A2-adenosine receptor to stimulatory guanine nucleotide-binding-protein in bovine brain striatum. J Pharmacol Exp Ther 266: 294-300.

Marangos PJ and Deckert J. 1987. [3H]dipyridamole binding to guinea pig brain membranes: possible heterogeneity of central adenosine uptake sites. J Neurochem 48: 1231-1236.

Marchi M, Raiteri L, Risso F, Vallarino A, BonFAnti A, Monopoli A, Ongini E AND Raiteri M. 2002. Effects of adenosine A1 and A2a receptor activation on the evoked release of glutamate from rat cerebrocortical synaptosomes.Br J Pharmacol 136: 434-440

Messersmith EK and Redburn DA. 1993. The role of GABA during development of the outer retina in the rabbit. Neurochem Res 18: 463-470.

Mockel V, Lohrke S and Hofmann HD. 1994. Diversity of neuronal phenotypes expressed in monolayer cultures from immature rabbit retina. Vis Neurosci 11: 629-642.

Newman ME. 1983. Relationship of the inhibition of epinephrine-stimulated adenylate cyclase in turkey erythrocytes by adenosine to its ' R-' and 'P-site'”mediated effects. Biochem Pharmacol 32: 37-40.

Nimit Y, Law J and Daly JW. 1982. Binding of 2',5'dideoxyadenosine to brain membranes. Comparison to P-site inhibition of adenylate cyclase. Biochem Pharmacol 31: 3279-3287.

Ohta A And Sitkovsky M. 2001. Role of G-proteincoupled adenosine receptors in downregulation of in- flammation and protection from tissue damage. Nature 414: 916-920.

Okada M, Nutt DJ, Murakami T, Zhu G, Kamata A, Kawata Y and KaneKo S. 2001. Adenosine receptor subtypes modulate two major functional pathways for hippocampal serotonin release. J Neurosci 21: 628-640.

Oliet SHR and Poulain DA. 1999. Adenosine-induced presynaptic inhibition of IPSCs and EPSCs in rat hypothalamic supraoptic nucleus neurones. J Physiol 520: $815-825$.

Ongini E, Adami M, Ferri C and Bertorelli R. 1997. Adenosine A2a receptors and neuroprotection. Ann N Y Acad Sci 825: 30-48

Paes-De-Carvalho R. 1987. Desenvolvimento do sistema purinérgico em retina de pinto: Regulação do sistema dopaminérgico embrionário por receptores A1 de adenosina. Tese de Doutorado (PhD thesis), Institute of Biophysics C. Chagas Filho UFRJ, Rio de Janeiro Brazil.

Paes-De-Carvalho R. 1990. Development of A1 adenosine receptors in the chick embryo retina. J Neurosci Res 25: 236-242.

Paes-de-Carvalho R and de Mello FG. 1982. Adenosine-elicited accumulation of adenosine 3'-5' cyclic-monophosphate in the chick embryo retina. J Neurochem 38: 493-500.

Paes-de-Carvalho and de Mello FG. 1985. Expression of A1 adenosine receptors modulating dopamine-dependent cyclic AMP accumulation in the chick embryo retina. J Neurochem 44: 845-851.

Paes-de-Carvalho R and Maia GA. 1996. Adenosine modulates neuronal survival in purified avian retinal cultures. Soc. Neurosci. Abstr. 22 (part 2): 1485.

Paes-de-Carvalho R, Braas KM, Snyder SH and ADLER R. 1990. Analysis of adenosine immunoreactivity, uptake and release in purified cultures of developing chick embryo retinal neurons and photoreceptors. J Neurochem 55: 1603-1611.

Paes-de-Carvalho R, Braas KM, Adler R and SnyDER SH. 1992. Developmental regulation of adenosine A1 receptors, uptake sites and endogenous adenosine in the chick retina. Dev Brain Res 70: 87-95.

Paes-de-Carvalho R, de Faria MH, do Nasci- 
MENTO JLM AND HoKoç JN. 1996. Development of NADPH-diaphorase in the avian retina: Regulation by calcium ions and relation to Nitric Oxide Synthase. J Neurochem 67: 1063-1071.

PARKINSON FE. 1999. Distribution of equilibrative, nitrobenzylthioinosine-sensitive nucleoside transporters (ENT1) in brain. J Neurochem 73: 867-873.

Perez MT and BruUn A. 1987. Colocalization of (3H)adenosine accumulation and GABA immunoreactivity in the chicken and rabbit retinas. Histochemistry 87: 413-417.

Perez MT, Ehinger BE, Lindstrom K And Fredholm BB. 1986. Release of endogenous adenosine and radioactive purines from the rabbit retina. Brain Res 398: 106-112.

Poli A, Di Iorio P, Beraudi A, Notari S, Zaccanti F, Villani L and Traversa U. 2001.The calciumdependent $[3 \mathrm{H}]$ acetylcholine release from synaptosomes of brown trout (Salmo trutta) optic tectum is inhibited by adenosine A1 receptors: effects of enucleation on $\mathrm{A} 1$ receptor density and cholinergic markers. Brain Res 892: 78-85.

Premont J, Perez M And Bockaert J. 1977. Adenosine-sensitive adenylate cyclase in rat striatal homogenates and its relationship to dopamine- and $\mathrm{Ca} 2+-$ sensitive adenylate cyclases. Mol Pharmacol 13: $662-670$.

Rey HL AND Burnside B. 1999. Adenosine stimulates cone photoreceptor myoid elongation via an adenosine A2-like receptor. J Neurochem 72: 2345-2355.

Roth S. 1995. An adenosine receptor antagonist decreases post-ischemic hyperemia in the retina. Curr Eyer Res 14: 323-328.

Salceda R AND Vilchis MC. 1994. High affinity uptake of glutamate and aspartate in the developing rat retina. Curr Eye Res 13: 297-302.

Sampaio LF and Paes-de-Carvalho R. 1998. Developmental regulation of group III metabotropic glutamate receptors modulating adenylate cyclase activity in the avian retina. Neurochem Int 33: 367-374.

Santos PF, Caramelo OL, Carvalho AP and DUARTE CB. 1998a. [3H] acetylcholine release from rat amacrine-like neurons is inhibited by adenosine A1 receptor activation. Neuroreport 9: 3693-3698.

Santos PF, Santos MS, Carvalho AP and Duarte
CB. 1998b. Modulation of [3H]acetylcholine release from cultured amacrine-like neurons by adenosine A1 receptors. J Neurochem 71: 1086-1094.

Santos PF, Caramelo OL, Carvalho AP and Duarte CB. 1999. Characterization of ATP release from cultures enriched in cholinergic amacrine-like neurons. J Neurobiol 41: 340-348.

Santos PF, Caramelo OL, Carvalho AP and Duarte CB. 2000. Adenosine A1 receptors inhibit $\mathrm{Ca} 2+$ channels coupled to the release of $\mathrm{ACh}$, but not of GABA, in cultured retina cells. Brain Res 852:1015.

Sattin A and Rall TW. 1970. The effect of adenosine and adenine nucleotides on the cyclic adenosine 3',5'-phosphate content of guinea pig cerebral cortex slices. Mol Pharmacol 6: 13-23.

SHaH BH AND Hausman RE. 1993. Effects of cell signaling on the development of GABA receptors in chick retina neurons. Neurochem Res 18: 957-964.

Sholl-Franco A, Marques PM, Paes-de-Carvalho R ANd Araujo EG. 2000. Effect of spleen-cellconditioned medium on $[3 \mathrm{H}]$-choline uptake by retinal cells in vitro is mediated by IL-2. Neuroimmunomodulation 7: 195-207.

Sholl-Franco A, Marques PM, Paes-De-Carvalho R AND Araujo EG. 2001. Antagonistic and synergistic effects of combined treatment with interleukin-2 and interleukin- 4 on mixed retinal cell cultures. J Neuroimmunol 113: 40-48.

Sinclair CJ, Powell aE, Xiong W, LaRiviere CG, Baldwin SA, Cass CE, Young JD and ParkinSON FE. 2001. Nucleoside transporter subtype expression: effects on potency of adenosine kinase inhibitors. Br J Pharmacol 134: 1037-1044.

Snell BJ, Short JL, Drago J, Ledent C And LAWRENCE AJ. 2000. Characterization of central adenosine $\mathrm{A}(1)$ receptors and adenosine transporters in mice lacking the adenosine $\mathrm{A}(2 \mathrm{a})$ receptor. Brain Res 877: 160-169.

Soares HC, Reis RA, de Mello FG, Ventura AL and Kurtenbach E. 2000. Differential expression of $\mathrm{D}(1 \mathrm{~A})$ and $\mathrm{D}(1 \mathrm{~B})$ dopamine receptor mRNAs in the developing avian retina. J Neurochem 75: 10711075.

Spence SG And Robson JA. 1989. An autoradiographic 
analysis of neurogenesis in the chick retina in vitro and in vivo. Neurosci 32: 801-812.

Stellwagen D, Shatz CJ and Feller MB. 1999. Dynamics of retinal waves are controlled by cyclic AMP. Neuron 24: 673-685.

StILES GL. 1985. The A1 adenosine receptor. Solubilization and characterization of a guanine nucleotidesensitive form of the receptor. J Biol Chem 260: 6728-6732.

Studholme KM and Yazulla S. 1997. 3H-adenosine uptake selectively labels rod horizontal cells in goldfish retina. Vis Neurosci 14: 207-212.

TAlukder MA, Morrison RR, Jacobson MA, JaCobson KA, Ledent C And Mustafa SJ. 2002. Targeted deletion of adenosine $\mathrm{A}(3)$ receptors augments adenosine-induced coronary flow in isolated mouse heart. Am J Physiol Heart Circ Physiol 282: H2183H2189.

van Calker D, Muller M and Hamprecht B. 1979. Adenosine regulates via two different types of receptors, the accumulation of cyclic AMP in cultured brain cells. J Neurochem 33: 999-1005.

van Galen PJ, van Bergen AH, Gallo-Rodriguez C, Melman N, Olah E, IJzerman AP, Stiles GL AND JACOBSON KA. 1994. A binding site model and structure-activity relationships for the rat A3 adenosine receptor. Mol Pharmacol 45: 1101-1011.

Varella MH, de Mello FG and Linden R. 1999. Evidence for an antiapoptotic role of dopamine in developing retinal tissue. J Neurochem 73: 485-492.
Ventura AL And de Mello FG. 1990. D1 dopamine receptors in neurite regions of embryonic and differentiated retina are highly coupled to adenylate cyclase in the embryonic but not in the mature tissue. Brain Res 530: 301-308.

Ventura AL, Klein WL and de Mello FG. 1984. Differential ontogenesis of D1 and D2 dopaminergic receptors in the chick embryo retina. Brain Res 314 : 217-223.

Visser F, Vickers MF, Ng AML, Baldwin SA, Young JD AND CASs CE. 2002. Mutation of residue 33 of human equilibrative nucleoside transporters 1 and 2 alters sensitivity to inhibition of transport by dilazep and dipyridamole. J Biol Chem 277: 395-401.

Wu PH, Phillis JW, Balls K and Rinaldi B. 1980. Specific binding of $2-[3 \mathrm{H}]$ chloroadenosine to rat brain cortical membranes. Can J Physiol Pharmacol 58: $576-579$.

Yasuyoshi H, Kashit S, KiKuchi M, Zhang S, Honda Y AND AKaike A. 2002. New insight into the functional role of acetylcholine in developing embryonic rat retinal neurons. Invest Ophthalmol Vis Sci 43: 446-451.

Yeung SM AND GREEN RD. 1984. [3H]5'-N-ethylcarboxamide adenosine binds to both $\mathrm{Ra}$ and $\mathrm{Ri}$ adenosine receptors in rat striatum. Naunyn Schmiedebergs Arch Pharmacol 325: 218-225. 